Самостални истраживач

\title{
КЊИЖЕНСТВО КРОЗ ПРИЗМУ МОДЕРНОСТИ: АНОТИРАНА БИБЛИОГРАФИЈА ${ }^{1}$
}

\begin{abstract}
Сажетак: Циљ рада јесте представљање радова који обрађују практичне и теоријске аспекте пројекта “Књиженство, теорија и историја женске књижевности на српском језику до 1915. године” кроз анотирану библиографију. Рад ће бити представљен кроз призму ауторовог ужег поља истраживања које подразмева изучавање модерности.
\end{abstract}

Кључне речи: Књиженство, модерност, анотирана библиографија, периодика, база података.

\section{1. Увод}

Пројекат Книженство, теорија и историја женске книжевности на српском језику до 1915. године (Кюиженство) као један од циљева има упознавање шире академске заједнице са посебностима женске књижевности као засебног жанра. Пројекат то чини путем базе података о српским књижевницама из датог периода и кроз научни допринос аутора који објављују у часопису Кюиженство, часопис за студије рода, кюижевности и културе. Путем ових главних активности пројекат доприноси укључивању српских књижевница из наведеног периода у српски књижевни канон. ${ }^{2}$

Рад на пројекту укључио је и израду анотиране библиографије текстова који се баве теоријским и практичним аспектима целог пројекта. У овом раду ће та анотирана библиографија бити представљена. У складу са интердисциплинарним приступом који пројекат Книженство негује, одлучио сам се да анотирану библиографију обогатим повезивањем са својим истраживачким радом у вези са модерношћу. Наиме, идеја којом

1 Овај рад је настао у оквиру пројекта бр. 178029 Министарства просвете, науке и технолошког развоја Републике Србије, Кьиженство, теорија и историја женске књижевности на српском језику до 1915. године.

2 За више детаља о пројекту видети: http://www.knjizenstvo.rs/ 
сам се водио јесте да радови који се баве пројектом Књиженство указују на његов шири значај који се огледа не само у доприносу женској књижевности већ и у изучавању модерности. Како би се ова тврдња поткрепила, указаћу на схватање модерности којим се руководим у раду, а потом и на везу између овог појма и пројекта Книженство.

\section{2. Модерност}

Модерност је термин у друштвеним и хуманистичким наукама којим се означава историјски период као и скуп одређених друштвено-културних норми, ставова и пракси. Аутори који се баве темом модерности, дефинишу овај термин на различите начине. Маршал Берман, у свом делу All That Is Solid Melts Into Air, сугерише да модерност садржи широк спектар повезаних историјских кретања и културних појава, као и субјективних искустава која те појаве производе и континуирани утицај на културу, политику и институције (подвукао С.П.) (Berman 15-36). Љиљана Марковић истиче да „напредак људских друштава и културног развоја, поседовање знања и његово повећање које доводи до развоја у области технологије, економије и људских послова, неизбежно доводи до уништень старог и стварана новог" (подвукао С.П.) (Marković 421). Важно је напоменути да реч уништење у овом контексту нема негативну конотацију и не указује на разарање, већ се користи у функцији ревизије- преиспитивању старих и прихватању нових вредности и знања. Поред наведеног, модерност подразумева и одбацивање или испитивање традиције, прелазак из феудализма у капитализам, стварање државе-нације; напредак у друштвеном, технолошком и научном смислу.

\section{3. Модерност и Књиженство}

Установљавање везе између овако дефинисаног појма модерности и пројекта Книженство темељи се на схватању овог пројекта као скупа идеја које заступају вредности које модерност носи са собом. С обзиром на то да модерност подразумева идеју ревизије старог и успостављања новог, јасно је да један пројекат који тежи да у студије књижевсноти унесе женску перспективу која до сада није сагледана у потпуности, доприноси остваривању ове идеје. Пројекат Книженство ствара платформу за откривање, обједињавање и омогућавање развоја дискурса о женском 
стваралаштву у доба модерности у Србији. Тиме пројекат доприноси указивању на недостајућу перспективу књижевног, културног и друштвеног живота у Србији на прелазу векова. Перспектива коју Књиженство отркива нуди детаљан поглед у до сада махом неистражено женско стваралаштво на српском језику. На тај начин стичемо увид у потпунију и дехијерархизовану слику српског друшта у време прихватања модерности.

Коришћењем метода дигиталне хуманистике, путем оснивања и одржавања електронске базе података и часописа, пројекат доприноси и самим студијама модерности. Ради указивања на значај ових активности у оквиру пројекта за шире истраивачке подухвате, приређена је анотирана библиографија. Она садржи радове који сажимају доприносе пројекта Кюиженство и који могу бити коришћени у будућим истраживањима.

\section{4. Анотирана библиографија}

Анотирана библиографија тренутно садржи 30 јединица: 4 стручне монографије, 5 докторских дисертација, и 21 научни чланак и други саставни делови. До краја пројектног циклуса овај број ће се засигурно повећати, а циљ је да се направи комплетна анотирана библиографија радова који се баве теоријским и практичним аспектима целог пројекта. Библиографија је рађена по ISBD стандарду.

Приликом прикупљања и анализе радова за анотирану библиографију уочено је да је те радове могуће категорисати у четири категорије:

(1) радови који у већој мери обрађују практичне аспекте пројекта, као што је дигитална база података;

(2) радови који се баве гинокритиком, женском књижевношћу и књижевном теоријом;

(3) радови који се баве периодиком, тачније женским и феминистичким часописима;

(4) радови који обрађују више различитих горенаведених аспеката.

Бројеви којима су ове категорије означене ће у анотираној библиографији бити приказани након кратког описа како би се указало на то у коју од категорија су смештени радови за потребе овог рада.

Захваљујем се колегиници Марини Милошевић на помоћи да анотирана библографија прати сва правила библиотекарства. 


\section{Анотирана библиографија}

\section{Стручне монографије}

1.

\section{БАРАТ, Станислава, 1977-}

Феминистичка контрајавност : жанр женског портрета у српској периодици 1920-1941. / Станислава Бараћ. - Београд : Институт за књижевност и уметност, 2015 (Београд : Службени гласник). - 434 стр. : илустр. ; 24 cm. - (Серија Историја српске књижевне периодике / Институт за књижевност и уметност, Београд ; 26)

«Ова књига је резултат рада на пројекту 'Улога српске периодике у формирању књижевних, културних и националних образаца'...” --> прелим. стр. - «Ова књига произишла је из моје докторске дисертације 'Жанр женског портрета у српској периодици 20-их и 30-их година 20. века', која је пријављена на Филолошком факултету у Београду...» --> Увод. - Тираж 300. - Прилози: стр. 402-412. - Напомене и библиогрфске референце уз текст. - Summary. - Селективна библиографија женских портрета (19201941): стр. 336-388. - Библиографија: стр. 289-[401]. - Регистри.

ISBN 978-86-7095-224-9 (брош.)

Кратак опис: Ова монографија представља прилагођену и допуњену верзију докторске дисертације ауторке. За кратак опис погледати приказ доктороске дисертације под редним бројем 1. (3)

\section{2.}

ДОЈЧИНОВИЋ, Биљана, 1963 -

Право сунца - другачији модернизми / Биљана Дојчиновић. - Нови Сад : Академска књига, 2015 ([Бачки Петровац : HL print]). - 166 стр. ; 23 cm. - (Библиотека Хоризонти / Академска књига, Нови Сад)

«... у оквиру пројекта ... Књиженство, теорија и историја женске књижевности на српском језику до 1915. године» --> полеђина насл. листа. - Тираж 1.000. - Белешка о ауторки: стр. [167]. - На корицама: Белешка о делу / Магдалена Кох. - Напомене и библиографске референце уз текст. - Библиографија: стр. 151-156. - Summary: стр. 157-162. - Индекс имена: стр. 163-166. - С а д р ж а ј: Предговор (7-11); Увод (13-16); Епифанија и аутобиографија (17-26); Места за којима се жуди (27-31); «Мала књижевност» или књижевност полупериферије (33-40); Другачији, а не други (41-47); Модернизам као полисистем (49-52); Нове жене (53-59); 
Повратак из сенке канона (61-74); Дубока трансгресија (75-88); Формативно читање као помно саосећање (89-97); Девојачки снови (99-110); Романи о ћутању (111-124); Софи међу зидовима (125-134); Кретање у некретању (135-144); Закључак (145-150). Библиографија (151-156). Summary (157-162). Индекс имена (163-166). Белешка о ауторки ([167]). ISBN 978-86-6263-087-2 (брош.)

Кратак опис: Монографија посвећена модернизму и по речима ауторке представља једну од "могућих шетњи кроз модернизам као светски феномен”. Књига се дели на два сегмента: Први део представља теоријска разматрања модернизма као вишедимензионалног књижевног покрета, док се други део бави превасходно књижевнм текстовима ауторки Јелене Димитријевић и Милице Јанковић, али говори и о првом роману Ребеке Вест и новели кинеске модернисткиње Динг Линг. (2)

\section{3.}

\section{КОЛАРИК, Ана, 1980-}

Род, модерност и еманципација : уредничке политике у часописима «Жена» (1911-1914) и «The Freewoman» (1911-1912) / Ана Коларић. - Београд : Фабрика књига, 2017 (Београд : Стандард 2). - 253 стр. : илустр. ; 23 cm. - (Едиција Реч / [Стандард 2, Београд] ; 102)

Тираж 300. - На корицама белешка о ауторки. - Поговор: стр. 239-241. - Напомене и библиографске референце уз текст. - Библиографија: стр. 245-253.

ISBN 978-86-7718-168-0 (брош.)

Кратак опис: Ова монографија представља прилагођену и допуњену верзију докторске дисертације ауторке. За кратак опис погледати приказ доктороске дисертације под редним бројем 2. (3)

4.

КОХ, Магдалена, 1958-

--- Када сазремо као култура --- : стваралаштво српских списатељица на почетку XX века : (канон - жанр - род) / Магдалена Кох ; превела с пољског Јелена Јовић. - Београд : Службени гласник, 2012 (Београд : Гласник). - 358 стр. : илустр. ; 24 cm. - (Библиотека Књижевне науке) (Колекција Основа)

Превод дела: --- Kiedy dojrzejemy jako kultura --- / Magdalena Koch. - Ayторкина слика на кор. - Тираж 500. - Стр. 331-352: Док сазревамо као 
култура / Биљана Дојчиновић. - Белешка о ауторки: стр. 355. - Напомене и библиографске референце уз текст. - Библиографија: стр. 307-318 и стр. 353-354. - Регистар.

ISBN 978-86-519-1503-4 (картон)

Кратак опис: Ауторка сагледава постојећи, успостављени српски књижевни канон и настоји да укаже на постојање модерне женске књижевне традиције на српском језику. Кроз призму феминистичке теорије, у раду се реконструише књижевна прошлост жена, врши се поновно ишчитавање и превредновање књижевне традиције како би се указало на женско присуство на књижевној сцени, и створила комплетнија слика књижевног живота у Србији на почетку XX века. (2)

\section{Докторске дисертације}

1.

\section{БАРАЋ, Станислава, 1977-}

Жанр женског портрета у српској периодици 20-их и 30-их година 20. века : докторска дисертација / Станислава М. Бараћ. - Београд : [С. Бараћ], 2014. - 452 листа : илустр. ; $30 \mathrm{~cm}+1$ електронски оптички диск (CD-ROM)

Доступно и на: http://phaidrabg.bg.ac.rs/o:10012. - На спор. насл. стр.: The female portrait genre in Serbian periodicals of the 1920's and 1930's. - Апстракт ; Summary. - Библиографија: листови 422-440. - Умножено за одбрану. - Универзитет у Београду, Филолошки факултет.

Кратак опис: Дисертација се бави жанром женског портрета у српској периодици двадесетих и тридесетих година 20. века. Тај жанр подразумева писање жена о одабраним женама и женским идентитетима са циљем женске еманципације. Рад кроз анализу периодике сагледава промене у јавној сфери и продор жена у јавни живот Србије. Кроз алманах Срикиюа, часопоис Жена, Јавор, листове Женски покрет, Једнакост, Југословенска жена, Жена данас, Жена и свет и Женски свет, ауторка анализира појаву новог жанра као и нове јавности, тачније феминистичке контрајавности у специфичном друштвено-културном и политичко-историјском тренутку. Кроз призму феминистичке теорије, сагледава се жанр женског портрета као битан чинилац у развоју женске периодике као и женске еманципације у датом периоду. (3) 
2.

\section{КОЛАРИК, Ана 3., 1980-}

Род, књижевност и модерност у периодици с почетка 20. века : Жена (1911-1914) и The Freewoman (1911-1912) : докторска дисертација / Ана 3. Коларић. - Београд : [А. Коларић], 2015. - 290 листова ; 30 cm + 1 електронски оптички диск (CD-ROM)

Доступно и на: http://phaidrabg.bg.ac.rs/o:10700. - На спор. насл. стр.: Gender, literature and modernity in periodicals from the early 20th century: Žena/The Woman (1911-1914) and The Freewoman; Гендер, литература и современность в периодике начала ХХ века: «Женщина» («Жена», 19111914) и «Фривумен» («The Freewoman», 1911-1914). - Библиографија: листови 278-289. - Апстракт ; Summery ; Резюме. - Умножено за одбрану. - Универзитет у Београду, Филолошки факултет.

Кратак опис: Докторска дисертација бави се анализом два часописа, лондонским часописом The Freewoman (1911-1912) и новосадским часописом Жена (1911-1914). Ауторка истражује везу између рода, књижевности и модерности. Часописи су тумачени у њиховим специфичним друштвеним, културним и политичким контекстима. Како би се извршила анализа између рода и модерности, изабране су три кључне теме као призма: женски идентитет, сексуалност и формирање и преиспитивање родних идентитета и њима условљених образаца понашања. Питања која дисертација обрађује су: шта је модерни иденститет; на које начине је женски покрет изменио поимање родних односа и улога; однос према сексуалности; улога женског стваралачког и критичарског рада. Часопис Жена налази се у бази података Книженство под категоријом 'серијске публикације’. (3)

\section{3.}

\section{МИЛИНКОВИК, Јелена, 1981-}

Женска књижевност у часопису Мисао : (1919-1937) : докторска дисертација / Јелена Г. Милинковић. - Београд : [J. Г. Милинковић], 2016. - 315 листова ; $30 \mathrm{~cm}+1$ електронски оптички диск (CD-ROM)

Доступно и на: http://phaidrabg.bg.ac.rs/o:11910. - На спор. насл. стр.: Woman's literature in magazine Misao [The Thought] : (1919-1937); Женская литература в журнале Мисао : (1919-1937). - Библиографија: листови 297-314. - Резиме ; Summary ; Резюме. - Умножено за одбрану. - Универзитет у Београду, Филолошки факултет. 
Кратак опис: Дисертација се бави анализом женске књижевности у међуратном часопису Мисао (1919-1937). Под женском књижевношћу ауторка подразумева текстове које су писале жене -- родна одређеност се узима као засебна категорија. Истраживање полази од закључака до којих се дошло на пројекту Кюиженство, теорија и историја женске кюижевности на српском језику до 1915. године, да се књижевни текстови сагледавају као део друштвеног контекста, дела која одсликавају спцифичне културно историјске, друштввене и политичко идеолошке околности у којима настају. Како је историја жена уско повезана са феминистичким покретом, женска књижевност је била у константном дијалогу са феминистичко-еманципаторким идејама. Промене у животима жена утицале су и на њихово стваралаштво. Анализом периодике ауторка указује на културно идеолошки и друштвено политички дух једног времена, као и на дух времена родних односа, и истражује у којој мери је женска књижевност допринела модернистичком дискурсу часописа. (3)

4.

\section{HЕMET, Софија, 1984-}

Брак и родне улоге у романима Излет на пучину и Госпођа Даловеј, Вирџиније Вулф : докторска дисертација / Софија Д. Немет. - Београд : [C. Немет], 2017. - ХХ, 244 листа ; 30 cm + 1 електронски оптички диск (CD-ROM)

Доступно и на: http://phaidrabg.bg.ac.rs/o:16879. - На спор. насл. стр.: Marriage and gender roles in Virginia Woolf's the voyage out and Mrs Dalloway ; Брак и гендерные роли в романах по Морю прочь и Миссис Дэллоуэй, Вирджинии Вулф. - Библиографија: листови 231-239. - Резиме ; Summary ; Заключение. - Умножено за одбрану. - Универзитет у Београду, Филолошки факултет.

Кратак опис: Дисертација се бави представом рода и теме брака у прозном стваралаштву Вирџиније Булф. У фокусу истраживања су теме и ликови романа Излет на пучину (1915) и Госпођа Даловеј (1925). кратких прича из постхумно објављене збирке Забаве код Госпође Даловеј, као и постхумно објављених рукописа под насловом Мелимброзија. Два есеја Сопствена соба (1929) и Три гвинеје (1938) служе превасходно као оквир за приказивање ауторовог феминистичког критичког става. Према речима ауторке, сва ова дела повезују тем,е род и брак. Цилј истраживања је да се пронађу сличности и разлика у карактеризацији "истих ликова". Кроз наведена дела прати се еволуција ликова Кларисе и Ри- 
чарда Даловеја, као појединаца и као брачног пара, у односу на културно историјске и друштвене околности. Истразен је лик Кларисе Даловеј као феминистичког лика у британском патрихархалом друштву, брака, као и контраста у карактеризацији лика Ричарда Даловеја. Основно питање је да ли се ови ликови, као и протагонисткиња романа Ижлет на пучину, Рејчел Бинрејс, развијају, да ли сазревају и да ли доживљавају просветљење. Основна питања су такође сличности и разлике у родној карактеризацији, и начин на који су њихове родне улоге мењане у делима обухваћеним анализом. (2)

\section{5.}

\section{ЂУРИЋ, Владимир, 1981-}

Стваралаштво српских списатељица прве половине XX века у контексту француске књижевности и културе : докторска дисертација / Владимир 3. Ђурић. - Београд : [В. Ђурић], 2017. - 321 лист ; $30 \mathrm{~cm}+1$ електронски оптички диск (CD-ROM)

Доступно и на: http://phaidrabg.bg.ac.rs/o:16870. - На спор. насл. стр.: Serbian women's literature in the first half of 20th century in the context of French literature and culture ; Творчество сербских писательниц первой половины XX века в контексте французской литературы и культуры ; Loeuvre littéraire des écrivaines serbes de la première moitié du XXe siècle dans le contexte de la littérature et de la culture françaises. - Библиографија: листови 287-304. - Резимеи на више језика. - Регистар. - Умножено за одбрану. Универзитет у Београду, Филолошки факултет.

Кратак опис: Дисертација се бави заступљеношћу француске књижевности и културе у стваралаштву српских књижевница прве половине $\mathrm{XX}$ века. Посебна пажња посвећена је текстовима Јелене Димитријевић, Исидоре Секулић, Ксеније Атанасијевић и Јулке Хлапец Ђорђевић. У анализи текстова користе се нове методе из француске компаратистике. Аутор представља стваралаштво горепоменутих српских списатељица кроз призму француске културе и књижевности; истаћи значај и домет француског језика и књижевности у српском женском стваралаштву; указати на везу између српских ауторки и француских ауторки и аутора савременика али и историјски удаљених стваралаца; истаћи значај читања читања текстова српских ауторки из прве половине XX века. Детаљним и дубоким прегледом и модерном анализом односа српске и француске књижевности, даје се допринос реафирмацији места српских списатељица у српском књижевном канону. (2) 


\section{Чланци и други саставни делови:}

1.

ANNOTATED Bibliography of Journals and Books on Gender Issues in Serbia 1991-2003 / Biljana Dojčinović... [et al]. - Način pristupa (URL): http:// www.knjizenstvo.rs/magazine.php. - Ostali autori: Minja Bujaković, Mina Marković, Marina Milošević, Teodora Todorić-Milićević. - Abstract У: Књиженство [Електронски извор]. - ISSN 2217-7809. - God. 8, br. 8 (2018).

Кратак опис: Ова анотирана библиографија нам приказује часописе и књиге које се баве родним питањима, објављеним у Србији током деведесетих година XX века, најтежим годинама у скоријој историји Сpбије и бивше Југославије. Библиографија је започета у склопу пројекта Центра за женске студије 2003. године, али је завршена тек 2018. године. (4)

2.

\section{ВУЧЕНОВИТ, Наташа}

Студије женске и феминистичке периодике у часопису „Књиженство” / Наташа Вученовић. Библиографија: стр. 343.

У: Феминистички часописи у Србији. Теорија, активизам и уметничке праксе у 1990-им и 2000-им / [уредиле Биљана Дојчиновић, Ана Коларић]. Београд : Филолошки факултет Универзитета, 2018. - ISBN 978-86-6153515-4. - Стр. 328-344.

Кратак опис: Осврт на часопис Книженство: часопис за студије книжевности, рода и културе као важног дела пројекта Книженство, теорија и историја женске книжевности на српском језику до 1915. године. Рад је подељен на два дела: у првом делу бави се анализом општих одлика часописа, док се други део бави радовима о женској и феминистичкој периодици. Рад потврђује значај часописа као извора за реконструкцију позиције жене у датом културно историјском периоду. (3)

3.

ГРУЈИТ, Драгана, 1976-

Књиженство - библиографија у електронском окружењу / Драгана Грујић, Гордана Ђоковић. - Библиографија стр. 203. - Апстракт; Summary. 
У: Значај библиографије периодике за истраживање књижевности и културе / уреднице Ана Ћосић-Вукић, Весна Матовић. - Београд : Институт за књижевност и уметност, 2014. - (Серија Историја српске књижевне периодике ; 23). - ISBN 978-86-7095-209-6. - Стр. 199-203.

Кратак опис: Ауторке представљају пројекат Кюиженство, са посебним освртом на електроски часопис, рубрику Библиограбије и аналитику публикација. Кроз библиографије публикације Српкиња и часописа Женски Свет сагледава се значај примене савремених библиографских правила аутоматизованом обрадом података у циљу формирања заједничек базе. (4)

4.

\section{ДОЈЧИНОВИЋ, Биљана, 1963 -}

Дигитална хуманистика и завере (не)читања / Биљана Дојчиновић. У: Poznańskie Studia Slawistyczne. - ISSN 2084-3011. - Год. 11 (2016), стр. 321-333.

Кратак опис: Текст одговара на питање какав је потенцијал дигиталне базе података у истраживању историје и теорије маргинализованих књижевности тј. женске књижевности. Фокус рада је база података Кюиженство, као и целокупан пројекат Кюиженство, теорија и историја женске къижевности на српском језику до 1915. године. (1)

\section{5.}

\section{ДОЈЧИНОВИТ, Биљана, 1963 -}

Иновација је увек преседан: пројекат Кюиженство, теорија и историја женске књижевности на српском језикудо 1915. године / Биљана Дојчиновић. - Библиографија: стр. 118-119.

У: Култура: у потрази за новом парадигмом : тематски зборник у 4 књиге. Књ. 2 / [уредник Љиљана Марковић ; превод Новица Петровић, Светлана Миливојевић Петровић, Милица Јелић]. - Београд : Филолошки факултет Универзитета, 2013. - ISBN 978-86-6153-190-3. - Стр. 105-120

Кратак опис: Текст говори о начинима на које је дигитална технологија променила поглед на историју и на теорију књижевности кроз пример базе података и електронског часописа Кюиженство. Ауторка указује на предности и мане које дигитална хуманистика доноси са собом. (1) 
6.

ДОЈЧИНОВИЋ, Биљана, 1963-

Историја дисциплине која то није: од појма рода до дигиталне хуманистике / Биљана Дојчиновић. - Напомене и библиографске референце уз текст. - Апстракт ; Summary. - Библиографија: стр. 83-84

У: Компаративна књижевност / приредиле Адријана Марчетић, Зорица Бечановић Николић, Весна Елез / edited by Adrijana Marčetić, Zorica Bečanović Nikolić, Vesna Elez. - Београд : Филолошки факултет, 2016. ISBN 978-86-6153-309-9. - Стр. 75-84.

Кратак опис: Рад се бави везом између дигиталне хуманистике и пројекта Книженство, терорија и историја женске книжевности на српском језику до 1915. године. Текст је подељен у два дела: први део посвећен је вези између интердисциплинарности и студија рода; други део бави се дигиталном хуманистиком и представљањем пројекта Книженство. (4)

7.

\section{ДОЈЧИНОВИТ, Биљана, 1963-}

Ка другачијем знању: база података Књиженство и дигитализација материјала / Биљана Дојчиновић, Ана Коларић. - Доступно и на: http://knjizevnaistorija.rs/docs/163/10_dojcinovic.pdf. - Напомене и библиографске референце уз текст. - Апстракт ; Summary. - Библиографија: стр. 209-210 У: Књижевна историја. - ISSN 0350-6428. - Год. 49, бр. 163 (2017), стр. 195 211.

Кратак опис: У првом делу рада ауторке представљају концепт дигиталне хуманистике и фазе у развоју хуманистике у дигиталним медијима, пре свега кроз дигиталну базу података Кнуженство, као и улогу дигиталне хуманистике у потврђивању маргинализованих књижевности, пре свега, књижевности коју су писале жене. Други део текста посвећен је проблему прикупљања, класификовања, и повезивања грађе феминистичких и женских часописа. (4)

8.

\section{ДОЈЧИНОВИЋ, Биљана, 1963-}

Книженство - в търсене на авторките в сръбската литература / Биляна Дойчинович. - Библиографија: стр. 166-167. 
У: Славянски диалози : списание за славянски езици, литература и култура. - ISSN 1312-5346. - Год. XII, бр. 16 (2015), стр. 150-167.

Превод наслова: Књиженство- потрага за женским ауторима у српској књижевности

Кратак опис: Овај рад се бави историјом женске књижевности на српском језику. Рад је подељен у три дела: први део представља изворе за стварање историје, и хронолошки представља могуће пионирке женске књижевности на српском језику. Други део посвећен је коментарима двеју монографија, а трећи део рада представља пројекат Кюиженство, теорија и историја женске књижевности на српском језику до 1915. године и прелазак из историјских студија у дигиталну хуманистику. (4)

9.

ДОЈЧИНОВИЋ, Биљана, 1963-

Књиженство : реафирмисање женске књижевне традиције = Knjiženstvo : a reaffirmation of women's literary heritage / Биљана Дојчиновић У: Књижевност и мултикултуралност / уредници Александра Вранеш, Љиљана Марковић. - Београд : Филолошки факултет Универзитета, 2013. - (Културе у дијалогу ; књ. 2). - ISBN 978-86-6153-181-1. - Стр. 37-38.

Кратак опис: Рад представља пројекат Кғиженство, теорија и историја женске къижевности на српском језику до 1915. године. Кроз базу података и часопис Кюиженство, ауторка се осврће на два аспекта овог пројекта: поновно оживљавање женске интерпретативне заједнице, а потом и на теоријске премисе и претпостављене резултате овог пројекта. (4)

10.

\section{ДОЈЧИНОВИТ, Биљана, $1963-$}

Компаративна књижевност и дигитална хуманистика на примеру база података Книженство и Women Writers in History / Биљана Дојчиновић. Библиографија: стр. 59.

У: Филологија културе : 4. међународна научна конференција, Београд, 9 - 11. јуна 2016. Зборник радова. Књ. 2 / [уредник Александра Вранеш, Љиљана Марковић ; превод Милица Јелић Мариоков]. - Београд : Филолошки факултет, 2016. - ISBN 978-86-6153-425-6. - Стр. 49-60. 
Кратак опис: Рад се заснива на упоредној студији историје женске књижевности и историје кљижевности такозваног главног тока. Кроз примере база Книженство, Women Writers in History и Virtual Research Environment, ауторка указује на важност и позитивни утицај дигиталне хуманистике на видљивост стваралаштва маргинализованих група, у овом случају женске књижевности на српском језику. (4)

11.

ДОЈЧИНОВИТ, Биљана, 1963-

Невоље са женским, невоље с књижевношћу: појмови женско писмо и гинокритика на полупериферији / Биљана Дојчиновић. - Библиографија: стр. 371-374.

У: Појмовник упоредне књижевности : зборник радова / [уредници Бојан Јовић, Тихомир Брајовић]. - Београд : Институт за књижевност и уметност, 2013. - ISBN 978-86- 7095-202-7. - Стр. 345-375.

Кратак опис: Ауторка текста бави се појмовима женско писмо и женска књижевност. Текст објашњава оригинална значења ових концепата и нуди алтернативе, течно писмо и кюиженство као појмове који тачније одговарају научним потребама данашњице, у контексту српске културе и књижевности. (2)

12. ДОЈЧИНОВИЋ, Биљана, 1963-

О гласу, путањи и месту: Десанка Максимовић у контексту истраживања женске књижевности" / Биљана Дојчиновић.

У: Над целокупним делом Десанке Максимовић, зборник радова / [уредио Станиша Тутњевић]. - Београд : Задужбина «Десанка Максимовић», 2013. - ISBN 978-86-82377-43-6. - Стр. 109-128.

Кратак опис: Рад се бави могућностима тумачења дела Десанке Максимовић из перспективе женске књижевности. Први део посвећен је поетским одликама збирке Тражим помиловағе (1964) из персепктиве теорија рода. У другом делу текста аутор се бави питањем места Десанке Максимовић у контексту Књиженства - женске књижевне традиције на српском језику. (2) 
13.

\section{ДОЈЧИНОВИТ, Биљана, 1963-}

Прихватање разлика: феминистичка критика у Србији у постсоцијалистичком периоду / Биљана Дојчиновић. - Библиографија: стр. 22-23. У: Феминистички часописи у Србији. Теорија, активизам и уметничке праксе у 1990-им и 2000-им / [уредиле Биљана Дојчиновић, Ана Коларић]. Београд : Филолошки факултет Универзитета, 2018. - ISBN 978-86-6153515-4. - Стр. 13-23.

Кратак опис: Текст представља историју интердисциплинарног поља феминисттичке критике у односу на књижевност као науку и на феминистичку теорију. Аутор сагледава почетке и продор феминистичких идеја у Југославији ван академске сфере. Други део текста посвећен је уласку теорије рода и разлике у академску сферу, оснивање пројекта Книженство као пројекат из дигиталне хуманистике као важном чиниоцу у превазилажењу и прихватању разлика. (4)

14.

ДОЈЧИНОВИЋ, Биљана, 1963-

Пројекат Книженство, теорија и историја женске книжевности на српском језику до 1915. / Биљана Дојчиновић . - Библиографија: стр. 60-61.

У: Креативне радионице у школској библиотеци. 2 / [уредник Александра Вранеш]. - Београд : Филолошки факултет Универзитета, 2012. - ISBN 978-86-6153-094-4. - Стр. 45-62.

Кратак опис: Овај рад је подељен на две целине. У првом делу текста представљен је пројекат Книженство, теорија и историја женске книжевности на српском језику до 1915. Представљена су два основна елемента пројекта, база података и часопис. Други део текста посвећен је теоријској и историјској позадини пројекта Книжентво. (4)

15.

ДОЈЧИНОВИЋ, Биљана, 1963-

Српске песникиње у Књиженству - часопис, зборник, база / Биљана Дојчиновић. - Напомене и библиографске референце уз текст. - Библиографија: стр. 190-192. - Summary.

У: Српске песникиње / [главни и одговорни уредник Емир Кустурица]. - Вишеград : Андрићев институт, 2018. - (Библиотека Научни скупови 
Одјељења за књижевност. Коло Зборници радова ; књ. 10). - ISBN 97899976-21-28-3. - Стр. 171-208.

Кратак опис: Текст се бави темом како су и у коликом броју предстваљене српске песникиње у пројекту Кюиженство, теорија и историја женске кюижевности на српском језику до 1915. године. Рад је подељен у два дела. Први део текста бави се присуством песникиња у часопису Кюиженство, тачније бројевима 5 и 6, и потом пезултате упоређује са базом података и штампаним зборником Кюиженство. Други део текста говори о мање познатим занимљивим примерима дела српских песникиња. (4)

16.

\section{ЂОКОВИЋ, Гордана, 1976-}

Библиографија српских песникиња у бази података Књиженство / Гордана Ђоковић, Драгана Грујић. - Овај рад је настао у оквиру пројекта бр. 178029 Министарства просвете, науке и технолошког развоја Републике Србије, Књиженство, теорија и историја женске књижевности на српском језику до 1915. године. - Напомене и библиографске референце уз текст. - Библиографија: стр. 173-174. - Summary.

У: Сусрети библиографа у спомен на др Георгија Михаиловића. - ISSN 1450-8699. - Год. 18 (2013), стр. 167-174.

Кратак опис: Ауторке кроз примере песникиња на прелазу векова, Еустахије Арсић, Мине Караџић- Вукомановић, Анке Обреновић и Марије Поповић Милутиновић представљају како се креира библиографија, изглед библиографије као и могућност претраживања. (1)

17.

\section{ЈОВАНОВИЋ, Татјана С., 1966-}

Књиженствени град: конституисање женског канона у српској прози / Татјана С. Јовановић. - Доступно и на: https://issuu.com/nbkg/docs/koraci_2017_br_7-9. - Белешка о аутору: стр. 179. - Напомене и библиографске референце уз текст

У: Кораци. - ISSN 0454-3556. - Год. 51, св. 7/9 (2017), стр. 108-111.

Кратак опис: У овом раду ауторка критикује статус кво српског књижевно-историјског канона, али и шире заступљеног једноумља у култури. Рад карактерише гинокритику и родне студије као примере 
борбе против игнорисања женског ауторства и и начина да се негује специфична женска историја и култура. (2)

18.

\section{КАЛТЕНБРУНЕР, ВолфГанг}

Scholarly Labour and Digital Collaboration in Literary Studies / Wolfgang Kaltenbrunner. - To link to this article (URL): https://doi.org/10.1080 /02691728.2014.907834.

Y: Social Epistemology: A Journal of Knowledge, Culture and Policy. - Vol. 29, Issue 3 (2014), p. 223-246.

Кратак опис: У овом тексту аутор испитује како специфични начини организовања научног рада омогућавају одређене облике знања и проучава препреке са којима се суочавају истраживачи када покушавају да прилагоде постојеће организационе моделе. Аутор се ослања на теренски рад у великом европском пројекту базе података, промовишући емпиријска знања о заборављеним женским писцима. (1)

19.

\section{МИлИНкОВИЋ, Јелена, 1981-}

Књиженство : база података као нови жанр / Јелена Милинковић. - Напомене и библиографске референце уз текст. - Библиографија: стр. 50-51. - Summary: Knjiženstvo - database as a new genre.

У: Књижевност и мултикултуралност / уредници Александра Вранеш, Љиљана Марковић. - Београд : Филолошки факултет Универзитета, 2013. - (Културе у дијалогу ; књ. 2). - ISBN 978-86-6153-181-1. - Стр. 39-52.

Кратак опис: Ауторка се у овом раду бави анализом базе података Книженство. Рад показује структуру базе, и прави посебан осврт на сличности и разлике између европске базе Women Writers и српске базе Кюиженство, сагледаних кроз призму великих и малих књижевности. Ауторка такође говори о доприносу интернета и дигиталног простора у науци и књижевности, посебно у био-библиографким ситематизацијама, као и о доприносу базе Кюиженство у студији књижевности које су писале жене и и сличним књижевно- историјским истраживањима. (1)

20.

СВИРЧЕВ, Жарка, 1983-

Нове перспективе историје књижевности: реконцептуализација 
жанра и канона / Жарка Свирчев. - Доступно и на: http://www.slavistickodrustvo.org.rs/pdf_dokumenti/Slavistika_XVII_2013.pdf. - Напомене и библиографске референце уз текст. - Резиме ; Резюме. - Библиографија: стр. 141.

У: Славистика. - ISSN 1450-5061. - Књ. 17 (2013), стр. 136-141.

Кратак опис: Ауторка говори о новинама у српској књижевној историофрафији са гинокритичког становишта. Посебна пажња је посвећена Биљани Дојчиновић, Ивани Живанчевић-Секеруш и Магдалени Кох, ауторкама које су на више начина допринеле књижевно-историјском дискурсу, и преобликовању српског књижевног канонског корпуса. Рад се такође бави концептом историје књижевности као "хипертекстовног књижевноисторијског архива” кроз пример пројекта Книженство. (2)

21.

\section{СИМИЋ, Зорана}

„Књиженство”: сусрет гинокритике и дигиталне хуманистике / Зорана Симић. - Библиографија: стр. 326.

У: Феминистички часописи у Србији. Теорија, активизам и уметничке праксе у 1990-им и 2000-им / [уредиле Биљана Дојчиновић, Ана Коларић]. Београд : Филолошки факултет Универзитета, 2018. - ISBN 978-86-6153515-4. - Стр. 315-327.

Кратак опис: Рад описује пројекат Кюиженство, теорија и историја женске књижевности на српском језику до 1915. године. Ауторка текста пројекат сагледава из две перспективе: као наслеђе гинокритике, и из перспективе дигиталне хуманистике. Текст одговара на питање зашто је употреба савремених алата за хуманистичка истраживања важна у данашње време. (4)

\section{Извори и литература}

BERMAN, Marshall. All That Is Solid Melts Into Air: The Experience of Modernity. Harmondsworth, Middlesex, England: Penguin Books. 1988.

MARKOVIĆ, Ljiljana. "Japan, the First Quest of Modernization in East Asia". European Review, Vol. 23, No. 3. Academia Europea. 2015. pp. 421-425. 


\section{Sava Popović}

Independent researcher

\section{KNJIŽENSTVO THROUGH THE PRISM OF MODERNITY: AN ANNOTATED BIBLIOGRAPHY}

Summary: The paper is a presentation of works addressing theoretical and practical aspects of the project "Knjizenstvo, Theory and History of Women's Literature in Serbian until 1915" through an annotated bibliography. The research will be presented through the prism of the author's field of interest which is modernity.

Keywords: Knjiženstvo, modernity, annotated bibliography, periodicals, database. 